\title{
The CSR-CFP relationship in the presence of institutional voids and the moderating role of family ownership
}

\author{
James J. Cordeiro ${ }^{1} \cdot$ Ambra Galeazzo $^{2}$ (D) $\cdot$ Tara Shankar Shaw $^{3}$
}

Received: 12 March 2020 / Revised: 16 March 2021 / Accepted: 11 May 2021 /

Published online: 28 May 2021

(c) The Author(s) 2021

\begin{abstract}
In weak institutional contexts characterized by institutional voids, firms often struggle to demonstrate their ethical conduct. They are seen as raising the costs of influencing stakeholders and correspondingly the level of investment needed in stakeholder influence capacity in order to achieve corporate financial performance (CFP). We hypothesize and find support for a U-shaped curvilinear relationship between corporate social responsibility (CSR) engagement level and CFP in the context of India-a country characterized by relatively weak institutions. We also investigate whether family firms can help overcome the drawbacks of weak institutional contexts and thus influence the relationship between CSR and CFP. We adopt a large sample, panel data approach to test our theoretical model. We observe a U-shaped relationship, consistent with earlier findings in developed countries. However, we find that this significant U-shaped relationship is observed only in the case of family firms in our sample.
\end{abstract}

Keywords CSR $\cdot$ Financial performance $\cdot$ India $\cdot$ Stakeholder influence capacity Family firms · Institutional voids

Ambra Galeazzo

ambra.galeazzo@unipd.it

James J. Cordeiro

jcordeir@brockport.edu

Tara Shankar Shaw

tara.shankar.shaw@gmail.com

1 School of Business, State University of New York, Brockport, 115B Hartwell Hall, 350 New Campus Drive, Brockport, NY 14420, USA

2 Dipartimento Di Scienze Economiche e Aziendali "Marco Fanno", University of Padova, Via Del Santo, 33, Padova, Italy

3 Indian Institute of Technology (IIT) Bombay, Adi Shankaracharya Marg, Powai, Mumbai, Maharashtra 400076, India 


\section{Introduction}

Asian companies have increasingly focused attention on corporate social responsibility (CSR) (Kim \& Moon, 2015; Xiao et al., 2018; Xu \& Zeng, 2020), especially in India where the 2013 Companies Act mandates that large, profitable firms invest two percent of net income in CSR activities. Through CSR, companies demonstrate their commitment towards the minimization of environmental and social issues and the improvement of economic development. Research has identified several benefits associated with CSR such as operating efficiencies, capital market benefits, risk management, reduced lawsuits, earnings quality, and many other stakeholder-derived benefits. These include increased sales, employee productivity, reduced risks that have favorable impacts on cash flows, risk, and growth (Barnett et al., 2018; Cordeiro \& Tewari, 2015; Shiu \& Yang, 2017; Yang \& Rhee, 2020). Despite these benefits, empirical evidence has found mixed results on whether the relationship between CSR and corporate financial performance (CFP) is positive or negative (Orlitzky, 2011; Orlitzky et al., 2003).

Moreover, recent literature has argued that it exists a U-shaped relationship between CSR and CFP (Barnett \& Salomon, 2012), suggesting that the direction of the linkage CSR-CFP depends on the company's relationship with key stakeholders (Barnett, 2007). Specifically, companies that invest insufficiently to influence key stakeholders are unable to achieve the financial benefits that flow from the satisfaction of stakeholder demands and interests, and thus lose money until they develop adequate stakeholder influence capacity (SIC), i.e., "the ability of a firm to identify, act on, and profit from opportunities to improve stakeholder relationships through CSR" (p. 803). After this point, they see increasing financial returns.

The mixed evidence on the CSR-CFP linkage can be attributed to the previous studies' scarce investigation of the role of the external context (Barnett, 2007; Campbell, 2007; Wang et al., 2016). This is particularly relevant when comparing Western companies with Asian companies of emerging economies (Hou et al., 2016; Li et al., 2010) like India, that suffer from institutional voids. Institutional voids, according to institutional theory, emerge because of weak governance, legal and monitoring mechanisms in a specific institutional context (Ioannou \& Serafeim, 2012; Lanis \& Richardson, 2015). In such contexts, stakeholders are less capable of monitoring the companies' irresponsible behaviors and tend to evaluate CSR actions with more skepticism compared to context without institutional voids (Amaeshi et al., 2016; Jamali \& Karam, 2018; Pureza \& Lee, 2020; Yang \& Rhee, 2020). Thus, companies will probably struggle to develop strong relations and engagement with stakeholders, who as a group generate most of the financial returns to CSR engagement (Cordeiro \& Tewari, 2015; Servaes \& Tamayo, 2013). However, past literature has not paid attention on determining how CFP is affected by CSR actions embedded in contexts with institutional voids, leaving unanswered the question on whether there is a positive, negative or U-shaped relationship between CSR and CFP. Hence, in this research, we address this question that deserves attention given the need for managers to justify expensive and risky investments on CSR in emerging economies. 
In addition, a company's ability to successfully engage in CSR actions that improve CFP may be determined by internal firm characteristics that may minimize the issues associated with institutional voids. Family firms are generally seen as 'substitutive' informal institutions (Estrin \& Prevezer, 2011) that offset the weaknesses of institutional voids. They are particularly important in India, whose industrial network is mostly populated by family-owned companies (Mani, 2019). Family firms pursue not only financial wealth but also "socio-emotional wealth" (SEW) (Gomez-Mejia et al., 2007; Berrone et al., 2010). SEW refers to intangible wealth that derives from the control of the family business, and comprises affective values such as identity, social ties, pride and need of preservation of the family traditions through the business. The pursuit of SEW suggests stronger motivation for family firms to improve CSR compared to non-family firms, including in Asian emerging economies such as India (Cordeiro et al., 2018; Yu et al., 2015). As a consequence, we should expect a linear positive relationship between CSR and CFP for family firms because they do not need to build SIC, having already a positive image among stakeholders, who probably perceive SEW as a form of social insurance, also in the presence of institutional voids.

However, some studies highlight that family firms could actually misbehave (for example, family members exploit their social ties to commit unethical activities) in emerging economies (Gaaya et al., 2017), implying that investments in SEW go through the same legitimation issues associated with SIC. We might therefore expect a curvilinear relationship between CSR and CFP for family firms because SEW is not sufficient and they need to build SIC to gain financial benefits from CSR. All in all, it is unclear whether the presence of family firms changes the shape and direction of the relationship between CSR and CFP in emerging economies. Accordingly, we complement the research question of this study, i.e., investigating the relationship between CSR and CFP in emerging economies, by shedding light on whether family firms moderate the effect of CSR on CFP.

We address the research question of this study in the Indian context, characterized by the presence of institutional voids, by using suitably sophisticated panel data econometric models to provide a robust examination of the nature of the relationship between CSR and CFP and of the moderating role of family firms. In contrast to previous studies on Indian CSR that have often suffered from a paucity of objective, large sample, longitudinal data analyses, thus comprising their statistical power, our study is based on a longitudinal dataset of 411 non-financial Indian firms. We operationalize CSR as an objective rating of CSR engagement developed by the NGO Karmayog (Karmayog, 2011). We operationalize CFP using both accounting-based (return on assets, ROA) and market-based measures (the twelve-month annualized stock return). Our fixed effects (FE) panel regression analyses support a curvilinear, rather than a linear effect of CSR on CFP for Indian firms, consistent with Barnett and Salomon (2012). Moreover, we study the moderating role of family ownership in the CSR-CFP relationship by using split-sample regression estimations. Our results find that only family firms display such a curvilinear relationship, in contrast to their non-family counterparts, consistent with our arguments that family firms are not only more likely to invest at or above the necessary SIC threshold but are also more likely to receive a positive financial return on its investment. 
Our study contributes to the literature in a number of ways. First, we extend the literature on the relationship between CSR-CFP providing evidence that such relationship is curvilinear in the context of emerging economies. Most studies in developing countries only assess whether there is a direct association between CSR and CFP (Hou et al., 2016; Xiao et al., 2018). Thus, our study is not meant to be another "me too" study; rather, we provide one of the first tests of the SIC model in the context of CSR-CFP relationships not just in the Indian context but also worldwide. The Indian context is of particular interest not only because it provides an interesting opportunity to test the theory in an emerging economy, weak institutional context but also because there are very few studies on the financial impact of CSR in India per se (Mishra \& Suar, 2010 being a notable exception), and as noted, earlier, anticipated financial benefits are a potent driver of CSR engagement. Second, we contribute to the institutional theory (Amaeshi et al., 2016) by showing that the CSR-CFP curvilinear relationship holds in an Asian emerging economy such as India. Finally, we add to the literature on family firms and CSR (Berrone et. al., 2010; Block \& Wagner, 2014) and especially family firms in India (Cordeiro et al., 2018; Mani, 2019) by theorizing and testing for the different nature of the relationship in Indian family versus non-family firms using arguments based on socio-emotional wealth, reputation and legitimacy.

The remainder of the manuscript is organized as follows. First, we present an overview of the theoretical framework introducing the SIC model developed by Barnett (2007) and the role of institutional voids for CSR based on the institutional theory. We then discuss the institutional voids characterizing the Indian context. Second, we present the arguments supporting the hypotheses. Third, we describe the sample, the variable measures and the analyses employed. Forth, we show the findings of our analyses and robustness tests. Finally, we conclude the paper by discussing the findings and their theoretical and managerial implications and by presenting limitations and avenues for future research.

\section{Theoretical framework and background}

\section{Stakeholders and corporate financial performance benefits from CSR}

A substantial rationale for social responsibility initiatives is based on the advancement of stakeholder interests (Barnett, 2019; Cordeiro \& Tewari, 2015). In this view, firms undertake CSR to satisfy the demands of diverse stakeholders who help create financial wealth, since they provide access to key resources and also assist with riskbearing and reputation creation (Barnett \& Leih, 2018; Cordeiro \& Tewari, 2015). In the stakeholder view, particular attention is paid to "primary" stakeholders who are critical to the firm's operations (Barnett, 2019), help attract and retain valuable employees (Greening \& Turban, 2000) and customers (Servaes \& Tamayo, 2013). Serving more distal stakeholders such as the environment helps develop valuable capabilities (Hart \& Dowell, 2011).

In recent years, the SIC model developed by Barnett (2007) has helped advance the long-standing argument over stakeholder salience (Wood et al., 2018) by 
arguing that a key contingency driving firm profitability related to CSR investments is whether or not the level of investments are sufficient to influence key stakeholders. Firms that invest insufficiently to influence key stakeholders are unable to achieve the financial benefits that flow from the satisfaction of stakeholder demands and interests, and thus continue to lose money until they develop adequate SIC; after this point, they see increasing financial returns, and thus a U-shaped relationship is hypothesized to prevail.

To date, however, initial testing and support for this argument has been found in Western nations, with virtually no attention paid to emerging markets. We seek to remedy this deficiency. Our focus on emerging markets is to establish an important boundary condition for the SIC model, since emerging markets, besides having lower levels of CSR and sustainability efforts relative to their more developed counterparts, are typically characterized by institutional voids and by concentrated ownership among families, two features that typically do not prevail in the AngloAmerican contexts where the SIC model has been tested.

\section{Institutional theory and the importance of context for CSR}

Institutions comprise a "collections of rules and routines that define actions in terms of relations between roles and situations" (March \& Olsen, 1989, p. 160). Institutional theory has been widely used in the CSR literature in order to identify the extent to which formal and informal constraints of the social, political and economic environment affect firms' CSR efforts (Montiel \& Delgado-Ceballos, 2014). Prior research also shows that CSR affects financial performance differently depending on the institutional contextual factors of the host countries (Campbell, 2007; Hou et al., 2016; Li et al., 2010). We discuss specific impacts of institutional voids on CSR practice and impact below.

Institutional voids potentially impact proper market functioning, and difficulties in implementing and in realizing the impacts of CSR in particular. For example, higher levels of corruption might lead firms to rely more heavily on friend and family networks (Alon \& Hageman, 2013). Bribery, pollution and nepotism might also be perceived less negatively with low regional modernization (Redfern \& Crawford, 2010), thus impacting business and CSR practice and investments. Absent legitimate mechanisms for managing business-government relations, firms develop informal ties (Li et al., 2008), which are increasingly associated with corruption (Luo, 2006). Poor information transparency (Barnett et al., 2018), and the sparse presence of media and organizations that provide reputational rankings hurt societal ability to form accurate perceptions of corporate reputation (Barnett \& Leih, 2018; Deephouse et al., 2016). Weak equity and credit markets are characterized by high agency costs and information asymmetry, which impair access to resources and raise the costs of raising external capital (Dhaliwal et al., 2011). Finally, absent attention from stakeholders, firms rely on supplier-arranged audits to monitor their supply chain's environmental and social practices in emerging markets, a practice more likely to be associated with unsustainable supplier behaviors (Huq \& Stevenson, 2018). For example, governmental negligence in the gas leak in Bhopal (India) and the lack of 
institutional supervision on the infrastructural conditions and the labor practices in the Rana Plaza (Bangladesh) demonstrated that the weak institutional context could not adequately monitor CSR activities.

Firms operating in developing countries need therefore to understand how institutional voids affect their business and how to make decisions on how to allocate resources - CSR being a notable instance - that overcome information asymmetries, scarce law enforcement systems and other obstacles discussed above that are presented by a flawed institutional environment (Lin et al., 2015). We move next to a focus on institutional voids in the Indian context.

\section{Institutional voids in India}

India has witnessed a dramatic change since the economic liberalization and privatization of the 1980s and 1990s that increased wealth and industrialization but also exacerbated nation-wide social and environmental problems. In large measure this was related to the inability of weak institutions to adequately restrain corruption, bribery and other unethical commercial practices, thus affecting business in general (Lee \& Oh, 2007; Li et al., 2014), and CSR in particular (Zhao et al., 2014). Corruption is a key issue for India, which is ranked 80th in the 2019 Corruption Perception Index among 180 countries, in addition to having the highest bribery rate in the Asia Pacific region according to Transparency International (2017) with every seven of ten people having to pay a bribe to obtain public services.

The Indian institutional context is characterized by both pervasiveness and arbitrariness of corruption where the fruits of corruption (e.g. outcomes of bribery) are not always clear to specify. Moreover, low transparency of decisions and policies are associated with monetary losses of more than US\$2 billion to investors (Kripalani \& Hamm, 2009; Kaur \& Mishra, 2010). Despite an extensive array of rules and a legal system rooted in the British tradition, the country is also plagued by poor enforcement of business laws due to inefficient court systems with more than 22 million cases pending in Indian courts in recent years (Doshi, 2016).

A lack of Campbell's (2007) recommended institutional mechanisms for communication between government institutions and different stakeholders may also undercut Indian firms' CSR efforts at least insofar as they target stakeholder relations. CSR in India is focused on addressing poverty, hunger and malnutrition, lack of education, gender equality, water, and fostering sanitation, preventive health care, and environmental sustainability. Much of CSR activity in India thus occurs in rural and under-developed contexts where the lack of a strong institutional system might also make it harder for stakeholders such as governmental agencies, NGOs and advocacy groups to assess CSR compliance or proactive efforts, leading firms to engage into symbolic rather than substantive activities to retain or enhance their existing legitimacy and reputation with stakeholders (Cormier et al., 2004; Perez-Batres et al., 2012). Firms may thus overstate accomplishments to stakeholders through greenwashing for example (Marquis et al., 2016). In this regard, Pope and Wæraas (2016) highlight that most stakeholders believe that Indian firms are CSR-washing, i.e., asserting false or misleading CSR claims by exaggerating achievements and 
minimizing poor track records. Some Indian firms have also utilized CSR activities primarily as a way to gain tax benefits in past decades. Such alternative motivations for tax saving and legitimacy gains decoupled from actual CSR accomplishments fuel stakeholder skepticism (Mukundhan et al., 2019; Narwal \& Sharma, 2008).

In terms of regulation, self-regulation continues to dominate Indian business with very few civil society organizations and labor unions actively involved in the CSR effort (Chahoud et al, 2007). Other challenges to external assessment of CSR initiatives include the lack of community participation in CSR initiatives, insufficient capacities of local NGOs focused on CSR, issues of limited transparency in terms of a perception that partner NGOs and local implementation agencies inadequately share information or disclose progress (Das Gupta, 2014).

For all the reasons discussed above, we argue that Indian firms need to invest in SIC at least as much and likely more than their Western counterparts. This provides theoretical reasons for the view that the SIC model of Barnett (2007) should apply in the Indian context.

\section{The impact of Indian institutional voids on SIC: a curvilinear CSR-CFP relationship}

Past literature posits that the breadth of CSR implementation is strongly influenced by pressure from salient stakeholders that scrutinize companies' actions especially if their interests are threatened (Chung et al., 2019; Yang \& Rhee, 2019), and can thus withhold the stakeholder-derived benefits from CSR discussed earlier. India has a long tradition of integration between business and social responsibilities toward stakeholders. Indeed, Balakrishnan et al. (2017) explain how the trusteeship model proposed by Gandhi, which remains influential among Indian entrepreneurs and managers, can be considered an antecedent of CSR that draws on the need to balance self-interest with social welfare.

Other literature has empirically shown a positive relationship between stakeholder pressures and CSR performance in the Indian context. For example, in their exploration of the determinants of proactive environmental practices in Indian firms, Singh et al. (2014) highlight that internal stakeholders, such as owners and employees, as well as customers and suppliers drive firms to adopt proactive environmental practices. The expectations of institutional actors can buttress these efforts. Brand image, reputation, customer loyalty and other stakeholder motives for CSR in the developed world have not yet made their mark in India's fast-changing consumer and business environment, where the CSR multi-stakeholder approach is still quite fragmented (Chahoud et al., 2007). However, given the aspirations of Indian firms to be global players in the context of an ever-increasing pro-CSR global corporate sentiment, is likely to overcome this fragmentation and lead to a more unified strategic orientation towards CSR. This sentiment is echoed in a number of surveys (Arevalo \& Aravind, 2011; Gautam \& Singh, 2010; Mitra, 2012; Sagar \& Singla, 2004) that point to the growing importance of CSR for Indian firms.

Being socially responsible is costly because CSR puts firms under ongoing scrutiny that is expensive to bear (Jensen, 2002). While acknowledging that firms have to pursue profit, stakeholders are less likely to trust and reward firms if CSR actions are 
perceived as helping society but also directly benefiting the firm, as in the case, for example, of charity donations that are not altogether altruistic (Barnett, 2019). Firms therefore must develop competencies to gain social legitimacy, generate moral capital and being perceived as fair (Hasan et al., 2018). These competencies are costly to develop, especially given the typically large number of targeted stakeholders. Overall, developing and maintaining stakeholder relations requires ongoing investments in order to reap the benefits of CSR activities.

The institutional voids discussed earlier impede CSR efforts by hindering stakeholder ability to correctly assess the extent and legitimacy of CSR engagement, engendering reluctance to provide expected financial rewards to CSR. Stakeholders might mistrust corporate disclosure of their CSR programs and other information on their business ethics (Das Gupta, 2014). Indian business professionals, for example, state that both the social importance of economic and physical security and the level of corruption limit the extent to which they commit to the environmental and social dimensions of corporate sustainability (Ralston et al., 2015). Indian firms investing in CSR also have to face the remedial costs of information provision given insufficient community information and interest about CSR, and the lack of agencies, especially local NGOs, with adequate competences and expertise in monitoring and supporting CSR activities.

Overall, the hindrances imposed by institutional voids or weak institutions in India point to the importance of corporate investments in communication and trustbuilding in order to sufficiently inform stakeholders of social and environmental CSR (Bai \& Chang, 2015). Beyond communications, Indian firms will also need to deploy performance evaluation, strategic planning, and performance measurement systems to support CSR initiatives and demonstrate that CSR is an integral part of the corporate strategy (Das Gupta, 2014), especially given the relative unfamiliarity of Indian firms with CSR. ${ }^{1}$

The costs associated with all these efforts in terms of communications, trustbuildings, performance evaluation, planning and performance measurement, largely comprise the costs of developing SIC (Barnett, 2007; Barnett \& Salomon, 2012). Specifically, higher levels of CSR effort accrue higher SIC costs. Barnett (2007) and Barnett and Salomon (2012) theorize the existence of a U-shaped relationship between CSR engagement and financial performance, based on the logic that firms need to go beyond superficial investment in order to develop sufficient capacity to influence stakeholders. They thus argue that firms with higher SIC will have higher (and positive) financial returns but only if they have accumulated the minimum necessary SIC; those with insufficient investment in SIC who persist in CSR engagement are generating negative financial returns since the returns from improved stakeholder relations are insufficient to cover the costs of CSR, absent sufficient SIC.

\footnotetext{
1 As a recent commentator notes, it may be that "...(Indian firms) are not well equipped to identify the right vehicles for their CSR spends. Which is why I expect a certain amount of chaos, confusion and randomness when it comes to allocating these funds, and, more importantly, tracking them from an outcome point of view (Nadar, 2015, p. 41)".
} 
Overall, the presence of institutional voids where information asymmetries are high, corruption widespread and institutional context opaque, significant investment in CSR with the aim of accruing adequate SIC can reduce information asymmetries and effectively signal the success of CSR outcomes and develop beneficial relationships with salient stakeholders (Montiel et al., 2012). However, the costs of these improved stakeholder relationships will arguably be reflected in high SIC levels being necessary in weak institutional contexts, such as in India, as compared to their developed nation counterparts. This should support the expected U-shaped relationship between CFP and CSP theorized and observed by Barnett and Salomon (2012) in the US, developed country context. Therefore, we hypothesize that we will observe a U-shaped relationship between CSR and CFP. ${ }^{2}$

Hypothesis 1: There will be a curvilinear (U-shaped) relationship between CSR and CFP in India.

\section{The CSR-CFP relationship in family versus non-family firms}

Pervasive family ownership especially might work as a 'substitutive' informal institution (Estrin \& Prevezer, 2011) that offsets the weakness of Indian institutions, which is especially important for assessing CSR efforts. For example, Ding et al. (2016) find that family firms are less likely to engage in bribery behavior in countries with weak institutional contexts. Cennamo et al. (2012) demonstrate that family firms tend to anticipate stakeholders' demands, thus showing a proactive social behavior. Therefore, family owned and controlled firms provide the foundation for developing social capital that is conducive to the creation of positive relationships with stakeholders, including, notably, in countries where the presence of institutional voids can be a concern (Wright et al., 2005).

The rationale for family firms to behave differently from other firms and have a different CSR-CFP relationship is that family firms are not limited to the pursuit of financial gain, but strive for non-economically motivated objectives, defined as "socioemotional wealth" (SEW) (Berrone et al., 2010). Specifically, family firms reflect the history of a family because there is an overlap between the members of the family and its firm (Block \& Wagner, 2014). Moreover, they have a strong desire to cultivate a positive image among stakeholders because any damage on the firm image is expected

\footnotetext{
2 To date there is some mixed evidence of a positive linear relationship between CSR and CFP in the Indian context, that is compromised by the small sample sizes and cross-sectional analyses. Mishra and Suar (2010) used perceptual survey data from 150 senior Indian managers and related CSR scores aggregated across six stakeholder groups into a composite measure of CSR. They found that a favorable perception of managers towards CSR is positively associated with an increase in both financial and nonfinancial performance. Kapoor and Sandhu (2010) found a positive relationship between averaged CSR performance of 93 top companies and CFP (using averaged measures such as ROA, ROE) over 19992006. Cheung et al. (2010) found a positive relationship between CSR and financial performance in different Asian emerging markets including India over 2001-2004, using CSR scores from Credit Lyonnaise Securities. However, their study was unable to find the same positive relationship between CSR and financial performance for individual countries due to the small sample sizes for each country.
} 
to influence family image (Deephouse \& Jaskiewicz, 2013). In addition, families make decisions taking into consideration longer-term horizons compared to non-family firms in order to perpetuate firm survival and guarantee intra-family succession (Brigham et al., 2014; De Massis et al., 2008). They are also more committed to create a positive company reputation because it is tied up with the family reputation (Binz et al., 2013). Therefore, family firms not only pursue financial benefits but also aim to maintain image and preserve reputation, i.e. SEW (Berrone et al., 2010), which provides an incentive to commit to social objectives (Yu et al., 2015) that is much stronger among family controlled firms in contrast to firms managed by professional managers "whose relationship to the firm is more distant, transitory, individualistic, and utilitarian" (Berrone et al., 2010, p. 87). The family's identification with the firm and the desire to be positively perceived by stakeholders will promote a strong, genuine commitment to CSR activities, thus gaining beneficial CFP effects.

Family business research shows that among family firms one way to achieve a superior image and reputation in the pursuit of SEW is to advance positive social performance, thus building up their stocks of goodwill and reputational capital with salient stakeholders (Cordeiro et al., 2018; Yu et al., 2015) through ethical behaviors and actions (Berrone et al., 2010; De Massis et al., 2008) thus seeking more than just financial gain (Wang \& Berens, 2015).

As noted previously, firms can invest in CSR nominally (in accordance perhaps with the pursuit of greenwashing or tax avoidance) and develop insufficient SIC to realize effective CSR outcomes. We hypothesize that family firms, as a subgroup, are more likely to invest in CSR at or beyond the necessary threshold required to accrue SIC (Barnett, 2007) given their strong interest in pursuing SEW through CSR. Secondly, since family firms in India have a longer history of altruistic and other meaningful CSR investments, their investments in CSR are likely to be viewed less cynically by stakeholders as being merely symbolic or as being driven by greenwashing motives. Therefore, family firms are more likely to overcome the drawbacks of mistrust, uncertainty and insecurity associated with the presence of institutional voids. Further, the investments necessary for CSR in Indian family firms may well be lower than non-family firms since socially responsible activities carried out by family firms are considered legitimate by various stakeholders given their historical association with meaningful philanthropy. These arguments suggest overall that family firms are more likely to invest at or above the necessary SIC threshold. Therefore, we expect the SIC model to hold more strongly in family firms, and thus we hypothesize that:

Hypothesis 2: Compared to non-family firms, family firms are more likely to have a U-shaped CSR- CFP relationship.

\section{Methods}

We tested our theoretical model using a fixed effects (FE) panel data regression that control for firm-specific unobserved time invariant effects that can arise from a number of sources such as corporate culture (McWilliams et al., 2006), management 
style (Hemingway \& Maclagan, 2004), and managerial discretion (Garcia-Castro et al., 2010) which impact the firm's CSR, and if uncontrolled for in the econometric specification, can yield inconsistent parameter estimates. Our use of FE panel estimation controls for these unobserved firm-specific effects by utilizing a within group transformation that cancels the effect of any potentially relevant unobserved variable that is constant across the study time period.

We utilize the Hausman-Wu test to confirm the appropriateness of using a FE model for our data over an alternative random-effects (RE) panel data model. We also performed the Woolridge (2002) test of serial correlation to confirm the appropriateness of the within group transformation rather than the first difference transformation for estimating the FE panel data model. Finally, we lagged the independent and other control variables on the right hand side by one period to mitigate the potential simultaneous determination of performance and the CSR activities of the firm.

Some control variables such as firm age, firm's sales and the dependent variable can change with time and might result in spurious correlation between explanatory and the dependent variable. To alleviate this problem, we follow the standard practice of including year dummies in the estimation. Thus, to test hypothesis 1 we estimated the model below:

$$
\begin{aligned}
\text { Performance }_{i t} & =\beta_{0}+\beta_{I} \text { CSR }_{i t-1}+\beta_{2} \text { CSR }_{i t-1}^{2}+\gamma \text { Control Variables } \\
& + \text { Firm Level Fixed Effect }{ }_{i}+\delta \text { Year Dummies }+\varepsilon_{i t}
\end{aligned}
$$

where the square of CSR captures the curvilinear effect of CSR on firm performance. Firm financial performance is measured using both return on assets (ROA) and the twelve-month annualized stock return. ROA is an accounting-based measure that reflects the firm's past short-term performance and is calculated as profit before interest and tax divided by total assets. On the other hand, the annualized stock return is a market-based measure reflecting the firm's future or long-term performance (Gentry \& Shen, 2010). To test hypothesis 2 we estimated Eq. 1 separately for family and non-family firm subgroups, thus using split-sample regression estimations.

\section{Data}

\section{CSR and CFP variables}

To measure CSR engagement, we used a new dataset of CSR ratings provided by the NGO Karmayog (Karmayog, 2011). Karmayog has been recognized as a trustful source for CSR ratings by several Indian media (visit the www.karmayog.com website for further details) and the dataset has recently been used in academic research (Cordeiro et al., 2018). In this dataset, the largest 500 companies in India are assessed on a scale from 0 to 5 based on their CSR initiatives. Companies obtain a rating of 0 or 1 if they produce liquor, tobacco, or genetically modified crops or they 
engage into activities that harm the environment or the society. Companies obtain a rating of 2 if they have implemented some initiatives to reduce their products' or processes' negative effects on the natural environment or the society. They obtain 3 if CSR initiatives in the local community or expenditures at least $0.2 \%$ of firm sales on CSR are reported. They obtain 4 if CSR is embedded in the company's operations and 5 if CSR plays a strategic role. We dropped financial firms and any firms that were merged with other firms in the sampling period.

To measure CFP, data was extracted from Prowess (Release 4.12) maintained by the Center of Monitoring Indian Economy. After merging the Karmayog CSR ratings for the year 2007-2010 with the financial data, we were left with 411 nonfinancial firms amounting to the 1420 unique firm-year data.

We determined a firm to be a family firm using the definition of Singla et al. (2014). Specifically, we coded "1" a firm being controlled by a family. Singla et al. (2014) argued that a firm is a family controlled firm if at least two out of the three criteria were met: "(1) the founding family had a stake of $20 \%$ or greater in the firm; (2) a member of the founding family was on the board of the firm; and (3) a member of the founding family was the chairman of the board; otherwise it was coded zero" (p. 611).

\section{Control variables}

We utilized controls for: (a) firm's governance including the size of the board and its square, the proportion of independent directors on the board, an indicator variable "duality" that takes the value 1 if the CEO of the firm is also the chairman of the board, and the proportion of independent directors who have multiple appointments; (b) the ownership structure of the firm that includes proportion of equity holding of Indian promoters and proportion of equity held by institutional investors, and; finally, (c) firm level variables that include firm size (operationalized as the natural log of firm sales to compensate for skewness in this variable), firm slack (operationalized as the ratio of working capital (i.e. current assets-current liabilities) to sales), firm leverage (operationalized as long-term debt divided by equity and the annual growth in firm sales), advertising intensity and R\&D intensity (both standardized by dividing by firm sales), and firm age.

\section{Results}

Table 1 reports the descriptive statistics of the variables both by individual years and across all years together, while Table 2 reports the variable inter-correlations.

The results of the fixed-effects (FE) panel data regression estimation are reported in Table 3. The Wooldridge (2002) test for first order auto-correlation of the error term in the FE estimation failed to reject the null hypothesis of no first-order auto correlation in all the estimations. Based on this, we estimated the model using FE estimation. While our hypothesis 1 posits a curvilinear relationship between CFP and CSR, for the sake of comparison, we have reported results with and without 
Table 1 Descriptive statistics

\begin{tabular}{lrrrrrrr}
\hline Variables & \multicolumn{2}{l}{ Average across year } & & \multirow{2}{*}{ All years } & SD \\
\cline { 2 - 5 } & \multicolumn{2}{l}{2007} & 2008 & 2009 & 2010 & & \\
\hline ROA & 0.197 & 0.207 & 0.194 & 0.203 & 0.1721 & 0.190 \\
Annualized stock return & -0.024 & -0.004 & -0.084 & 0.063 & -0.009 & 0.069 \\
CSR & 1.277 & 1.254 & 1.396 & 1.407 & 1.338 & 1.061 \\
Prop. of Indian promoter & 41.300 & 44.117 & 44.373 & 44.774 & 43.858 & 23.800 \\
Prop. of institutional promoters & 22.524 & 20.058 & 18.898 & 20.195 & 20.211 & 13.757 \\
Board size & 11.194 & 10.705 & 10.890 & 10.955 & 10.911 & 3.410 \\
Prop. of independent directors & 0.475 & 0.487 & 0.505 & 0.530 & 0.501 & 0.145 \\
CEO duality & 0.310 & 0.323 & 0.3124 & 0.310 & 0.314 & 0.464 \\
Prop. of multiple director & 0.493 & 0.502 & 0.493 & 0.506 & 0.499 & 0.241 \\
Slack & 0.187 & 0.177 & 0.170 & 0.202 & 0.1835 & 0.386 \\
Firm age & 31.647 & 32.600 & 33.600 & 34.518 & 33.647 & 22.906 \\
Advertising intensity & 0.012 & 0.010 & 0.010 & 0.043 & 0.019 & 0.351 \\
Debt to equity & 0.000 & 0.000 & 0.000 & 0.000 & 0.000 & 0.002 \\
R\&D intensity & 0.002 & 0.003 & 0.003 & 0.004 & 0.003 & 0.012 \\
Ln of sales & 10.000 & 9.925 & 10.087 & 10.222 & 10.063 & 1.205 \\
\hline
\end{tabular}

the squared term of CSR. The model without the squared CSR term represents a linear model in contrast to the curvilinear model incorporating the squared term. In Model 1 and Model 2, financial performance is measured by accounting ROA and, in Model 3 and Model 4, the performance of the firm is measured by annualized stock return. Model 1 and Model 3 report the results of the linear estimation and Model 2 and Model 4 report the results of the curvilinear relationship.

In Model 1 the coefficient of the CSR term is not significant; however, once we include the squared term of CSR in Model 2 both the level of CSR (Model 2: $\beta=-0.0163, p=0.014$ ) and the square of CSR (Model 2: $\beta=0.0048, p=0.032$ ) become significant. Similarly, in Model 3 the coefficient of CSR is not significant whereas in Model 4 both the level of CSR (Model 4: $\beta=-0.0128, p=0.047$ ) and the square of CSR (Model 2: $\beta=0.0061, p=0.005$ ) are significant. Thus, a linear relationship between CSR and CFP is not supported, while Hypothesis 1 arguing for a curvilinear (U-shaped) relationship is supported.

\section{Controlling for endogeneity}

Reverse causality might be an issue in our analysis because high-performing firms undertake higher CSR to build their reputation. As a result, the level of CSR is dependent on past firm performance. Although we addressed this issue estimated by including a one-year lag for performance in Eq. 1, FE estimation could lead to inconsistent parameter estimates. As a robustness check, we estimated Eq. 1 using the generalized method of moments (GMM) and different lags of the dependent 


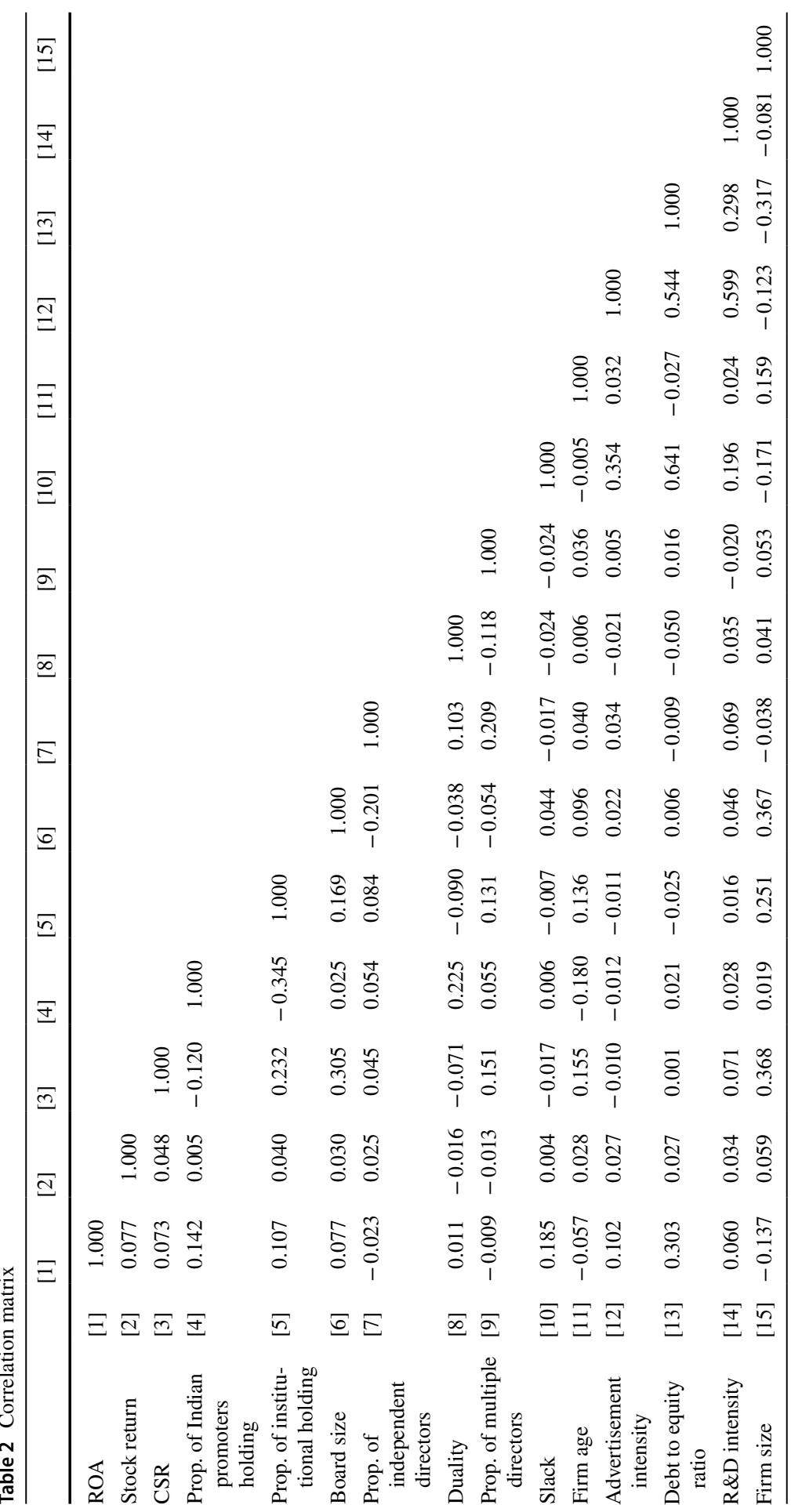


Table 3 Results of fixed effects estimation

\begin{tabular}{|c|c|c|c|c|}
\hline \multirow[t]{2}{*}{ Variables } & \multicolumn{2}{|l|}{$\operatorname{ROA}(t)$} & \multicolumn{2}{|l|}{ Stock return $(t)$} \\
\hline & Model 1 & Model 2 & Model 3 & Model 4 \\
\hline $\operatorname{CSR}(t-1)$ & $\begin{array}{l}-0.0036 \\
(0.003)\end{array}$ & $\begin{array}{l}-0.0163 * * \\
(0.007)\end{array}$ & $\begin{array}{l}0.0035 \\
(0.003)\end{array}$ & $\begin{array}{l}-0.0128 * * \\
(0.006)\end{array}$ \\
\hline Square of CSR $(t-1)$ & & $\begin{array}{l}0.0048 * * \\
(0.002)\end{array}$ & & $\begin{array}{l}0.0061 * * * \\
(0.002)\end{array}$ \\
\hline Proportion of Indian promoters holdings $(t-1)$ & $\begin{array}{l}0.0011 * * \\
(0.001)\end{array}$ & $\begin{array}{l}0.0011 * * \\
(0.001)\end{array}$ & $\begin{array}{l}0.0008 * \\
(0.000)\end{array}$ & $\begin{array}{l}0.0008 * * \\
(0.000)\end{array}$ \\
\hline Proportion of institutional holdings $(t-1)$ & $\begin{array}{l}0.0010 * * \\
(0.000)\end{array}$ & $\begin{array}{l}0.0010 * * \\
(0.000)\end{array}$ & $\begin{array}{l}0.0010^{* * * *} \\
(0.000)\end{array}$ & $\begin{array}{l}0.0010 \text { *** } \\
(0.000)\end{array}$ \\
\hline Board size $(t-1)$ & $\begin{array}{l}0.0006 \\
(0.003)\end{array}$ & $\begin{array}{l}0.0001 \\
(0.003)\end{array}$ & $\begin{array}{l}0.0018 \\
(0.003)\end{array}$ & $\begin{array}{l}0.0012 \\
(0.004)\end{array}$ \\
\hline Square of Board Size $(t-1)$ & $\begin{array}{l}-0.0001 \\
(0.000)\end{array}$ & $\begin{array}{l}-0.0001 \\
(0.000)\end{array}$ & $\begin{array}{l}-0.0001 \\
(0.000)\end{array}$ & $\begin{array}{l}-0.0001 \\
(0.000)\end{array}$ \\
\hline Proportion of independent directors $(t-1)$ & $\begin{array}{l}-0.0141 \\
(0.024)\end{array}$ & $\begin{array}{l}-0.0114 \\
(0.024)\end{array}$ & $\begin{array}{l}0.0110 \\
(0.016)\end{array}$ & $\begin{array}{l}0.0144 \\
(0.017)\end{array}$ \\
\hline CEO duality $(t-1)$ & $\begin{array}{l}-0.0023 \\
(0.009)\end{array}$ & $\begin{array}{l}-0.0026 \\
(0.009)\end{array}$ & $\begin{array}{l}0.0035 \\
(0.008)\end{array}$ & $\begin{array}{l}0.0032 \\
(0.010)\end{array}$ \\
\hline $\begin{array}{l}\text { Proportion of directors with multiple director- } \\
\text { ships }(t-1)\end{array}$ & $\begin{array}{l}-0.0168 \\
(0.022)\end{array}$ & $\begin{array}{l}-0.0147 \\
(0.022)\end{array}$ & $(0.017)$ & $(0.016)$ \\
\hline Slack $(t-1)$ & $\begin{array}{l}-0.0005 \\
(0.001)\end{array}$ & $\begin{array}{l}-0.0004 \\
(0.001)\end{array}$ & $\begin{array}{l}0.0000 \\
(0.001)\end{array}$ & $\begin{array}{l}0.0001 \\
(0.001)\end{array}$ \\
\hline Firm age $(t-1)$ & $\begin{array}{l}-0.0004 \\
(0.003)\end{array}$ & $\begin{array}{l}-0.0004 \\
(0.003)\end{array}$ & $\begin{array}{l}0.0346^{* * * *} \\
(0.002)\end{array}$ & $\begin{array}{l}0.0346^{* * * *} \\
(0.002)\end{array}$ \\
\hline Advertisement intensity $(t-1)$ & $\begin{array}{l}0.0234 * * * \\
(0.007)\end{array}$ & $\begin{array}{l}0.0234 * * * \\
(0.007)\end{array}$ & $\begin{array}{l}-0.0085 \\
(0.006)\end{array}$ & $\begin{array}{l}-0.0084 \\
(0.009)\end{array}$ \\
\hline Debt to equity ratio $(t-1)$ & $\begin{array}{l}0.0186 \\
(1.146)\end{array}$ & $\begin{array}{l}-0.1333 \\
(1.093)\end{array}$ & $\begin{array}{l}-11.531 \\
(1.058)\end{array}$ & $\begin{array}{l}-13.475 \\
(1.300)\end{array}$ \\
\hline R\&D intensity $(t-1)$ & $\begin{array}{l}-0.2686 \\
(0.327)\end{array}$ & $\begin{array}{l}-0.2481 \\
(0.321)\end{array}$ & $\begin{array}{l}0.3225 \\
(0.284)\end{array}$ & $\begin{array}{l}0.3489 \\
(0.337)\end{array}$ \\
\hline Firm size $(t-1)$ & $\begin{array}{l}0.0201 * \\
(0.012)\end{array}$ & $\begin{array}{l}0.0199 * \\
(0.012)\end{array}$ & $\begin{array}{l}-0.0186^{* * * *} \\
(0.006)\end{array}$ & $\begin{array}{l}-0.0189 * * * \\
(0.007)\end{array}$ \\
\hline Constant & $\begin{array}{l}-0.0380 \\
(0.083)\end{array}$ & $\begin{array}{l}-0.0306 \\
(0.082)\end{array}$ & $\begin{array}{l}-1.0659 * * * \\
(0.071)\end{array}$ & $\begin{array}{l}-1.0560 * * * \\
(0.070)\end{array}$ \\
\hline Time dummies & Yes & Yes & Yes & Yes \\
\hline Woolridge test of autocorrelation ( $p$-value) & 0.243 & 0.243 & 0.319 & 0.316 \\
\hline$R$-squared & 0.041 & 0.045 & 0.617 & 0.620 \\
\hline Observations & 1420 & 1420 & 1420 & 1420 \\
\hline Number of firms & 411 & 411 & 411 & 411 \\
\hline
\end{tabular}

Robust standard errors in parentheses

$* * * p<0.01, * * p<0.05, * p<0.1$ 
variable as instruments following the Arellano-Bond estimation (Arellano \& Bond, 1991; Roodman, 2009). Two tests were performed to examine the validity of the new estimations of Eq. 1. The first test assesses whether the error term has a significant first-order autocorrelation but an insignificant second-order autocorrelation. The second test assesses whether the instruments are over-identified by using Hansen and Sargan test.

Table 4 shows the results for both ROA and stock return. Both tests suggest that all the estimations are well specified because the error term has insignificant secondorder auto correlation and the Hansen and Sargan test of over-identification confirms that instruments are not over-identified. Results show that the coefficient of lagged ROA is not significant whereas the coefficient for lagged stock return is negative and significant. Furthermore, the value of CSR is negatively significant at levels (Model 1: $\beta=-0.0221 ; p=0.04$; Model 2: $\beta=-0.0158 ; p=0.04$ ) and the square of CSR is positive and significant (Model 1: $\beta=-0.0073 ; p=0.012$; Model 2: $\beta=-0.0070 ; p=0.02$ ). These results suggest that reverse causality is not an issue in our analyses.

\section{The role of family firms vs. non-family firms in the relationship between CSR-CFP}

We analyze the effect of CSR on performance for family firms and non-family firms by estimating Eq. 1 separately for these firms in subgroup regression estimations. The estimation results are reported in Table 5. Models 1-4 report the estimation results for family firms, while models 5-8 report those for non-family firms. In models $1,3,5$ and 7 we have included only the CSR variable (thus testing only for a linear effect of CSR on CFP) and in models 2, 4, 6 and 8 we have included both CSR and CSR squared terms to test for the hypothesized curvilinear effect. We find evidence of a curvilinear impact of CSR on firm performance in the case of family firms, since in model 2 and model 4 in Table 5 we find the effect of CSR on ROA and stock return to be negative and statistically significant (Model 2: $\beta=-0.0208 ; p=0.009$; Model 4: $\beta=-0.0217 ; p=0.006$ ) and the effect of squared CSR on ROA and stock return to be positive and statistically significant (Model 2: $\beta=0.0072 ; p=0.016$; Model 4: $\beta=0.0086 ; p=0.004$ ). In contrast, no such effect was observed in the case of non-family firms as Models 6 and 8 show. These findings support Hypothesis 2 that the impact of CSR on firm performance will be more consistent with SIC theory (in terms of a demonstrated curvilinear impact of CSR on CFP) in family firms than in their non-family counterparts. The pattern of results for the control variables is generally similar to those for the full models reported previously.

\section{Discussion}

This research aims at investigating the CSR-CFP relationship in India. Integrating Barnett and Salomon's (2012) model with literature on institutional voids in the theoretical context of institutional theory (Amaeshi et al. 2016; Ioannou \& 
Table 4 Results of the generalized methods of moments (GMM) estimation

\begin{tabular}{|c|c|c|}
\hline \multirow[t]{3}{*}{ Variables } & \multicolumn{2}{|c|}{ Arellano bond estimation } \\
\hline & $\mathrm{ROA}(t)$ & Stock return $(t)$ \\
\hline & Model 1 & Model 2 \\
\hline \multirow[t]{2}{*}{$\operatorname{ROA}(t-1)$} & 0.4637 & \\
\hline & $(0.293)$ & \\
\hline \multirow[t]{2}{*}{ Annualized stock return $(t-1)$} & & $-0.0715^{* *}$ \\
\hline & & $(0.035)$ \\
\hline \multirow[t]{2}{*}{$\operatorname{CSR}(t-1)$} & $-0.0221^{* *}$ & $-0.0158^{* *}$ \\
\hline & $(0.011)$ & $(0.008)$ \\
\hline \multirow[t]{2}{*}{ Square of CSR $(t-1)$} & $0.0073 * *$ & $0.0070^{* * *}$ \\
\hline & $(0.003)$ & $(0.003)$ \\
\hline \multirow[t]{2}{*}{ Proportion of Indian promoters holdings $(t-1)$} & 0.0013 & 0.0006 \\
\hline & $(0.001)$ & $(0.000)$ \\
\hline \multirow[t]{2}{*}{ Proportion of institutional holdings $(t-1)$} & $0.0014 * *$ & $0.0017 * * *$ \\
\hline & $(0.001)$ & $(0.000)$ \\
\hline \multirow[t]{2}{*}{ Board size $(t-1)$} & -0.0030 & 0.0018 \\
\hline & $(0.004)$ & $(0.003)$ \\
\hline \multirow[t]{2}{*}{ Square of board size $(t-1)$} & 0.0001 & -0.0001 \\
\hline & $(0.000)$ & $(0.000)$ \\
\hline \multirow[t]{2}{*}{ Proportion of independent directors $(t-1)$} & 0.0025 & 0.0101 \\
\hline & $(0.029)$ & $(0.018)$ \\
\hline \multirow[t]{2}{*}{ CEO duality $(t-1)$} & 0.0016 & 0.0052 \\
\hline & $(0.016)$ & $(0.008)$ \\
\hline \multirow[t]{2}{*}{ Proportion of directors with multiple directorships $(t-1)$} & -0.0087 & -0.0064 \\
\hline & $(0.024)$ & $(0.019)$ \\
\hline \multirow[t]{2}{*}{ Slack $(t-1)$} & -0.0000 & 0.0003 \\
\hline & $(0.000)$ & $(0.001)$ \\
\hline \multirow[t]{2}{*}{ Firm age $(t-1)$} & 0.0003 & $0.0303 * * *$ \\
\hline & $(0.004)$ & $(0.002)$ \\
\hline \multirow[t]{2}{*}{ Advertisement intensity $(t-1)$} & $0.0088^{*}$ & -0.0012 \\
\hline & $(0.005)$ & $(0.005)$ \\
\hline \multirow[t]{2}{*}{ Debt to equity ratio $(t-1)$} & 0.0174 & $-2.4074 * *$ \\
\hline & $(1.301)$ & $(1.032)$ \\
\hline \multirow[t]{2}{*}{$\mathrm{R} \& \mathrm{D}$ intensity $(t-1)$} & $0.3788^{*}$ & 0.2959 \\
\hline & $(0.225)$ & $(0.224)$ \\
\hline \multirow[t]{2}{*}{ Firm size $(t-1)$} & 0.0175 & $-0.0153^{*}$ \\
\hline & $(0.020)$ & $(0.008)$ \\
\hline Number of instruments & 20 & 20 \\
\hline $\operatorname{AR}(1)$ test ( $p$-value) & 0.014 & 0.000 \\
\hline $\operatorname{AR}(2)$ test ( $p$-value) & 0.662 & 0.370 \\
\hline Hansen test of over-identification ( $p$-value) & 0.601 & 0.481 \\
\hline Sargan test of over-identification ( $p$-value) & 0.174 & 0.536 \\
\hline Fixed effects & Yes & Yes \\
\hline Time dummies & Yes & Yes \\
\hline Observations & 990 & 964 \\
\hline Number of firms & 400 & 395 \\
\hline
\end{tabular}


Table 4 (continued)

Robust standard errors in parentheses

$* * * p<0.01, * * p<0.05, * p<0.1$

Serafeim, 2012; Lanis \& Richardson, 2015), we create and test a theoretical model that hypothesizes a curvilinear relationship between CSR and CFP. Moreover, this research investigates whether the theoretical model also holds when the ownership type is taken into consideration. Specifically, given the prevalence of family firms in India, we study whether the moderating role of family firms tightens or loosens the CSR-CFP relationship. Based on a panel database with 1420 unique firmyear data, the FE panel data regression estimations and the generalized method of moments (GMM) estimations yielded two main findings. First, there is a U-shaped relationship between CSR and CFP in the Indian context characterized by relevant institutional voids. Second, the U-shaped relationship between CSR and CFP in the Indian context holds for family firms but not for firms with other types of ownership. Together, these findings lead to important theoretical and managerial implications.

\section{Theoretical implications}

We provide several theoretical contributions. First, this study extends the literature investigating the relationship between CSR and CFP, providing additional valuable evidence on the question "does it pay to be socially responsible?" (Brammer \& Millington, 2008; Orlitzky, 2011). Our research adds to the sparse literature on the relationship between CSR and CFP in the context of India, an important emerging market economy. The CSR concept is increasingly extensively studied in these contexts (Visser, 2008), especially India (Cordeiro et al., 2018) and the large footprints of many emerging market firms (such as Tata in India) may help transmit domestic CSR practices overseas. In particular, by finding that the CSR-CFP curvilinear relationship holds in the Indian context, we demonstrate the importance of developing expertise and competences in dealing with stakeholders (SIC) (Barnett \& Salomon, 2012; Brammer \& Millington, 2008) also in non-Western, emerging market contexts. Indeed, we contribute to the literature by theoretically fleshing out SIC arguments in the presence of institutional voids. We seek to develop arguments based on how the weak institutional framework leads to information asymmetry and lack of transparency that attenuate stakeholders' ability to work with firms and assess their CSR performance. Given this, we maintain that firms in emerging economies must adequately invest in developing expertise and competencies that create a bond of trust with stakeholders in order to overcome the drawbacks of institutional voids (Montiel et al., 2012; Ralston et al., 2015; Wang \& Berens, 2015) and thus benefit financially from CSR investments.

In addition, this study sheds light on the role of institutional voids in Asian emerging countries in the case of the CSR-CFP relationship, thus contributing to institutional theory. Previous studies place a high value on the differences between developing vs. developed countries when CSR is under study (Jamali \& Karam, 


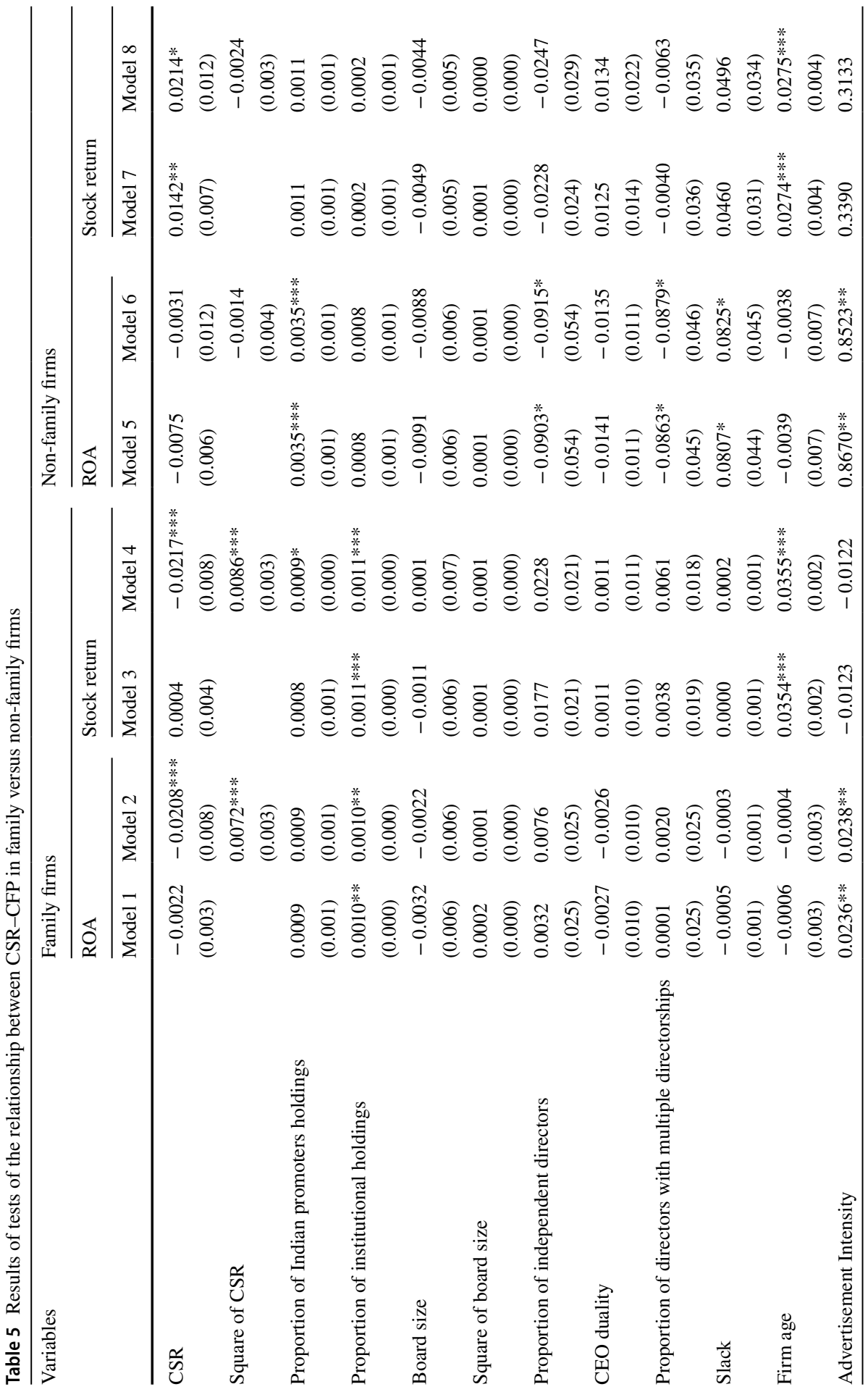




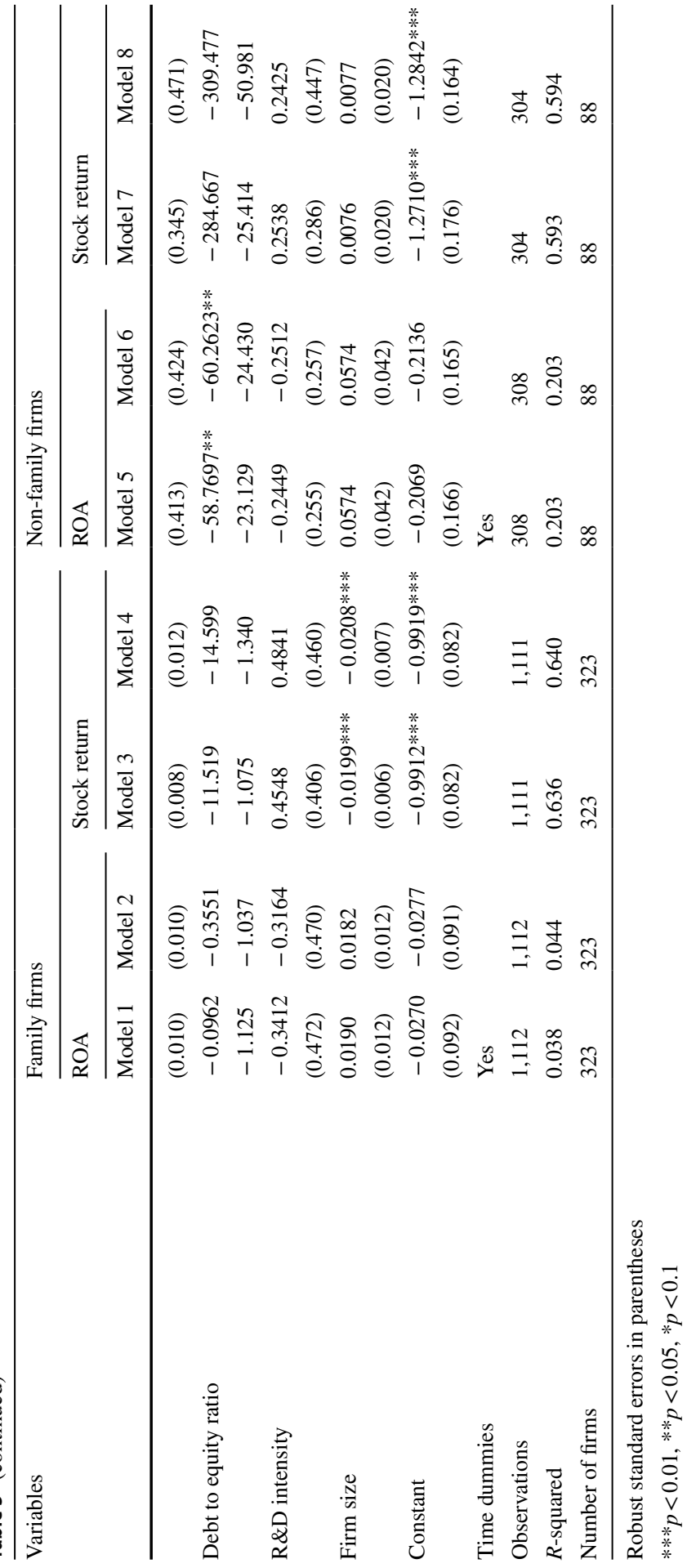

站。 
2018; Pureza \& Lee, 2020; Yang \& Rhee, 2020). By identifying that the SIC model of Barnett (2007) also holds in India, we demonstrate that the learning process associated with building up SIC is not dependent on the institutional context. In other words, SIC is not influenced by the institutional weaknesses related to the contextual environment. Rather, SIC is a capability that firms need to internally develop and only depends on internal endowments and resources.

Finally, this study contributes to the family business literature in emerging Asian economies. Though most studies argue that family firms aim at accruing SEW by investing in CSR (Cruz et al., 2014; Ye \& Li, 2021), there is still an open debate on whether family firms engage more or less in CSR than non-family firms (Dick et al., 2020; Yu et al., 2015). Some scholars argue that families have self-serving behaviors that result in nepotism, entrenchment and cronyism (Kellermanns et al., 2012) and that these behaviors lead them to be more focused on their own needs than those of stakeholders, especially employees and governance (Cruz et al., 2014). Our findings that the curvilinear CSR-CFP relationship is attributable mainly or solely to family firms in the sample demonstrate that stakeholders do not sufficiently endow family firms with trust and reputational advantages, suggesting SEW is not sufficiently perceived as a form of social insurance that offsets the weakness of institutional voids. As a consequence, firms need to create strong relationships with stakeholders, by accruing sufficient SIC in order to gain financial benefits from CSR improvements. This might be due to the lack of strong institutions that do not provide sufficient supervision and safeguards to support the positive relationship between CSR and $\mathrm{CFP}^{3}$

\section{Managerial implications}

The paper provides three important managerial implications. First, our findings warn managers in Indian companies to expect that CSR investments lead to delayed, rather than immediate, financial benefits. Indeed, even if CSR might have potentially greater marginal effects in developing countries relative to their Western counterparts, thereby expecting stakeholders reward CSR investments with increased financial returns, the presence of institutional voids with lower GDP, greater illiteracy, worse social welfare and public policy, as well as high level of corruption, may hinder stakeholders' ability to monitor and control the

\footnotetext{
3 There are good reasons why appraisal and monitoring of CSR performance may be hard case of family-owned firms, who might otherwise be viewed as potentially substitutive informal institutions (Estrin \& Prevezer, 2011). These firms are not subject to pressure from external capital markets, since they obtain capital from internal capital markets or from the government directly. Consequently, key investment (including CSR investment), expansion, diversification and personnel decisions continue to be made within the confines of the closed family circle, limiting transparency, accountability and ethical governance which are all necessary for effective CSR engagement, Moreover, in the family firm context, offsetting oversight from independent boards and activist shareholders are both in short supply in India (Sharma, 2013). Finally, much CSR spending occurs through foundations in India, where it is often unclear whether these foundation accounts are audited or made public. These concerns are heightened by a weak consumer voice and a general mistrust of voluntary industry initiatives due to weak accountability and enforcement (Sharma, 2013).
} 
firms, thus doubting about the legitimization of their CSR actions. For this reason, managers need to consider that CSR requires initial investments that are likely to decrease financial performance in the short term. Thus, managers must rely on long-term performance measures to assess the financial returns of CSR investments as short-term performance measures are unable to capture the real benefits of CSR.

Second, our findings highlight that the firm develops intangible resources, in the form of levels of SIC, while involving in profitable CSR activities. If managers have a hard time justifying socially responsible engagement to shareholders at the beginning of the CSR journey, they should explain shareholders that many benefits from CSR engagement will not be seen in the financial statements as they are intangible and are linked to the capacity of building trustful relationships with stakeholders (SIC). As a result, we suggest managers to create measures that assess SIC in order to take track of whether and how the firm is accruing trustful relationships with stakeholders in response to CSR actions.

Finally, our findings provide valuable insights for family firms in the Indian context offering a guiding principle on CSR investments. Family members need to expect short-term negative financial performance, followed by increasing returns afterwards. This implies that they should not only count on SEW to develop good relationships with stakeholders in order to build up SIC. Indeed, the competencies needed to improve SEW may not work as a substitute for increasing SIC. As a consequence, family firms need to dedicate appropriate resources to develop the relationships with stakeholders. We might expect that family members will be more prone than shareholders of non-family firms to support investments on SIC given their understanding of the importance of intangible assets such as SEW.

\section{Limitations and avenues for future research}

Our study is not without limitations that could be addressed in future research. First, future studies should test our hypotheses over longer time periods, thus further enhancing the robustness of our findings (especially when testing sub-samples such as family firms and non-family firms), but which is precluded at present due to limitations on obtaining relevant CSR data. Second, future studies should use alternative measures of CSR performance, especially if they can be partitioned by type of CSR, e.g. environmental versus educational or health-focused, since different types of CSR may have different financial payoffs or different time to payoff. Third, future researchers can advance and test theory by predicting more precisely how the moderating effect of family management and ownership will impact the curvilinear relationship that we explore in this research. In addition, in an emerging market context, the role of other ownership forms, such as multinational (MNC) status, and public ownership (PSU) status, needs to be explored as evidence on these ownership types will usefully complement our findings. Finally, future studies should test whether our findings of a U-shaped relationship hold in other Asian or developing economy contexts and should use the Tobin's Q as a measure of financial performance given 
that Tobin's Q in India is hard to estimate in terms of debt values and, therefore, difficult to use as an alternative measure of CFP.

\section{Conclusion}

The present paper addresses the important question "does it pay to be socially responsible?" by investigating the effect of CSR on CFP in the Indian context that, as other emerging economies in Asia, suffers from institutional voids. Our results reveal that there is a U-shaped relationship between CSR and CFP among Indian companies. Such curvilinear relationship demonstrates that Indian companies strive for building up resources and capabilities to develop trustful relationships with stakeholders to gain social legitimacy. These resources and capabilities are referred to as SIC based on Barnett (2007). SIC is costly to develop in the presence of institutional voids because stakeholders have scarce ability to scrutinize and eventually punish misbehaviors, thus doubting about the legitimization of companies' CSR actions. Without legitimization, Indian companies are unable to profit from CSR. However, Indian companies that keep accumulating SIC are able to eventually persuade stakeholders of the good of their CSR actions, even in the presence of institutional voids, thus increasing CFP. Furthermore, our results show that institutional voids are also relevant in determining a U-shaped relationship between CSR and CFP for Indian family firms. Overall, these findings highlight the importance of developing resources and competences such as SIC and SEW; explain the role of the institutional context with institutional voids such as India in the CSR-CFP relationship; and, offer a more fine-grained understanding of the moderating effect of ownership types such as family-controlled companies.

Funding Open access funding provided by Università degli Studi di Padova within the CRUI-CARE Agreement.

\section{Declarations}

Conflict of interest The authors declare that they have no conflict of interest.

Open Access This article is licensed under a Creative Commons Attribution 4.0 International License, which permits use, sharing, adaptation, distribution and reproduction in any medium or format, as long as you give appropriate credit to the original author(s) and the source, provide a link to the Creative Commons licence, and indicate if changes were made. The images or other third party material in this article are included in the article's Creative Commons licence, unless indicated otherwise in a credit line to the material. If material is not included in the article's Creative Commons licence and your intended use is not permitted by statutory regulation or exceeds the permitted use, you will need to obtain permission directly from the copyright holder. To view a copy of this licence, visit http://creativecommons.org/licen ses/by/4.0/. 


\section{References}

Alon, A., \& Hageman, A. M. (2013). The impact of corruption on firm tax compliance in transition economies: Whom do you trust. Journal of Business Ethics, 116(3), 479-494.

Amaeshi, K., Adegbite, E., \& Rajwani, T. (2016). Corporate social responsibility in challenging and nonenabling institutional contexts: Do institutional voids matter? Journal of Business Ethics, 134(1), $135-153$.

Arellano, M., \& Bond, S. (1991). Some tests of specification for panel data: Monte Carlo evidence and an application to employment equations. Review of Economic Studies, 58(2), 277-297.

Arevalo, J. A., \& Aravind, D. (2011). Corporate social responsibility practices in India: Approach, drivers, and barriers. Corporate Governance, 11(4), 399-414.

Bai, X., \& Chang, J. (2015). Corporate social responsibility and firm performance: The mediating role of marketing competence and the moderating role of market environment. Asia Pacific Journal of Management, 32(2), 505-530.

Balakrishnan, J., Malhotra, A., \& Falkenberg, L. (2017). Multi-level corporate responsibility: A comparison of Gandhi's trusteeship with stakeholder and stewardship frameworks. Journal of Business Ethics, 141(1), 133-150.

Barnett, M. L. (2007). Stakeholder influence capacity and the variability of financial returns to corporate social responsibility. Academy of Management Review, 32(3), 794-816.

Barnett, M. L. (2019). The business case for corporate social responsibility: A critique and an indirect path forward. Business \& Society, 58(1), 167-190.

Barnett, M., Henriques, I., \& Husted, B. (2018). The rise and stall of stakeholder influence: How the digital age limits social control. Academy of Management Perspectives, 39(1).

Barnett, M. L., \& Leih, S. (2018). Sorry to (not) burst your bubble: The influence of reputation rankings on perceptions of firms. Business \& Society, 57(5), 962-978.

Barnett, M. L., \& Salomon, R. M. (2012). Does it pay to be really good? Addressing the shape of the relationship between social and financial performance. Strategic Management Journal, 33(11), 1304-1320.

Berrone, P., Cruz, C., Gomez-Mejia, L. R., \& Larraza-Kintana, M. (2010). Socioemotional wealth and corporate responses to institutional pressures: Do family-controlled firms pollute less? Administrative Science Quarterly, 55(1), 82-113.

Binz, C., Hair, J. F., Pieper, T. M., \& Baldauf, A. (2013). Exploring the effect of distinct family firm reputation on consumers' preferences. Journal of Family Business Strategy, 4(1), 3-11.

Block, J. H., \& Wagner, M. (2014). The effect of family ownership on different dimensions of corporate social responsibility: Evidence from large US firms. Business Strategy and the Environment, 23(7), 475-492.

Brammer, S., \& Millington, A. (2008). Does it pay to be different? An analysis of the relationship between corporate social and financial performance. Strategic Management Journal, 29(12), 1325-1343.

Brigham, K. H., Lumpkin, G. T., Payne, G. T., \& Zachary, M. A. (2014). Researching long-term orientation. Family Business Review, 27(1), 72-88.

Campbell, J. L. (2007). Why would corporations behave in socially responsible ways? An institutional theory of corporate social responsibility. Academy of Management Review, 32(3), 946-967.

Cennamo, C., Berrone, P., Cruz, C., \& Gomez-Mejia, L. R. (2012). Socioemotional wealth and proactive stakeholder engagement: Why family-controlled firms care more about their stakeholders. Entrepreneurship Theory and Practice, 36(6), 1153-1173.

Chahoud, T., Emmerling, J., Kolb, D., Kubina, I., Repinski, G., \& Schläger, C. (2007). Corporate social and environmental responsibility in India-assessing the UN global compact's role (Vol. 26, p. 127). DEU.

Cheung, Y. L., Tan, W., Ahn, H. J., \& Zhang, Z. (2010). Does corporate social responsibility matter in Asian emerging markets. Journal of Business Ethics, 92(3), 401-413.

Chung, C. Y., Cho, S. J., Ryu, D., \& Ryu, D. (2019). Institutional blockholders and corporate social responsibility. Asian Business \& Management, 18(3), 143-186.

Cordeiro, J., \& Tewari, M. (2015). Firm characteristics, industry context, and investor reactions to environmental CSR: A stakeholder theory approach. Journal of Business Ethics, 130(4), 833-849.

Cordeiro, J., Galeazzo, A., Shaw, T. S., Veliyath, R., \& Nandakumar, M. K. (2018). Ownership influences on corporate social responsibility in the Indian context. Asia Pacific Journal of Management, 35(4), 1107-1136. 
Cormier, D., Gordon, I. M., \& Magnan, M. (2004). Corporate environmental disclosure: Contrasting management's perceptions with reality. Journal of Business Ethics, 49(2), 143-165.

Cruz, C., Larraza-Kintana, M., Garcés-Galdeano, L., \& Berrone, P. (2014). Are family firms really more socially responsible. Entrepreneurship Theory and Practice, 38(6), 1295-1316.

Dasupta, A. (2014). Implementing corporate social responsibility in India: Issues and beyond. In S. Ray \& S. Sivaaju (Eds.), Implementing corporate social responsibility: Indian perspectives ( $p p$ 19-29).Springer.

Dick, M., Wagner, E., \& Pernsteiner, H. (2020). Founder-controlled family firms, overconfidence, and corporate social responsibility engagement: Evidence from survey data. Family Business Review, 0894486520918724.

Doshi, V. (2016). India's Long wait for justice: 27M Court cases trapped in legal logjam. The Guardian, 6.

De Massis, A., Chua, J. H., \& Chrisman, J. J. (2008). Factors preventing intra-family succession. Family Business Review, 21(2), 183-199.

Deephouse, D. L., \& Jaskiewicz, P. (2013). Do family firms have better reputations than non-family firms? An integration of socioemotional wealth and social identity theories. Journal of Management Studies, 50(3), 337-360.

Deephouse, D. L., Newburry, W., \& Soleimani, A. (2016). The effects of institutional development and national culture on cross-national differences in corporate reputation. Journal of World Business, 51(3), 463-473.

Dhaliwal, D. S., Li, O. Z., Tsang, A., \& Yang, Y. G. (2011). Voluntary nonfinancial disclosure and the cost of equity capital: The initiation of corporate social responsibility reporting. The Accounting Review, 86(1), 59-100.

Ding, S., Qu, B., \& Wu, Z. (2016). Family control, socioemotional wealth, and governance environment: The case of bribes. Journal of Business Ethics, 136(3), 639-654.

Estrin, S., \& Prevezer, M. (2011). The role of informal institutions in corporate governance: Brazil, Russia, India, and China compared. Asia Pacific Journal of Management, 28(1), 41-67.

Garcia-Castro, R., Arino, M. A., \& Canela, M. A. (2010). Does social performance really lead to financial performance? Accounting for endogeneity. Journal of Business Ethics, 92(1), 107-126.

Gautam, R., \& Singh, A. (2010). Corporate social responsibility practices in India: A study of top 500 companies. Global Business and Management Research: an International Journal, 2(1), 41-56.

Gentry, R. J., \& Shen, W. (2010). The relationship between accounting and market measures of firm financial performance: How strong is it? Journal of Managerial Issues, 22(4), 514-530.

Hasan, I., Kobeissi, N., Liu, L., \& Wang, H. (2018). Corporate social responsibility and firm financial performance: The mediating role of productivity. Journal of Business Ethics, 149(3), 671-688.

Hemingway, C. A., \& Maclagan, P. W. (2004). Managers'personal values as drivers of corporate social responsibility. Journal of Business Ethics, 50(1), 33-44.

Hou, M., Liu, H., Fan, P., \& Wei, Z. (2016). Does CSR practice pay off in East Asian firms? A metaanalytic investigation. Asia Pacific Journal of Management, 33(1), 195-228.

Huq, F. A., and Stevenson, M. (2018). Implementing socially sustainable practices in challenging institutional contexts: Building theory from seven developing country supplier cases. Journal of Business Ethics, 1-28.

Ioannou, I., \& Serafeim, G. (2012). What drives corporate social performance? The role of nation-level institutions. Journal of International Business Studies, 43, 834-864.

Jamali, D., \& Karam, C. (2018). Corporate social responsibility in developing countries as an emerging field of study. International Journal of Management Research, 20, 32-61.

Jensen, M. C. (2002). Value maximization, stakeholder theory, and the corporate objective function. Business Ethics Quarterly, 235-256.

Kapoor, S., \& Sandhu, H. S. (2010). Does it pay to be socially responsible? An empirical examination of impact of corporate social responsibility on financial performance. Global Business Review, 11(2), $185-208$.

Karmayog, (2011). Announcing the Karmayog CSR ratings of India's largest 500 companies. Available at: http://www.karmayog.org/csr2010/ (accessed 25 October 2019).

Kaur, G., \& Mishra, R. (2010). Corporate governance failure in India: A study of academicians' perception. IUP Journal of Corporate Governance, 9(1 \& 2), 99-112.

Kellermanns, F. W., Eddleston, K. A., Sarathy, R., \& Murphy, F. (2012). Innovativeness in family firms: A family influence perspective. Small Business Economics, 38(1), 85-101.

Kim, R. C., \& Moon, J. (2015). Dynamics of corporate social responsibility in Asia: Knowledge and norms. Asian Business \& Management, 14(5), 349-382. 
Kripalani, M., \& Hamm, S. (2009). Corporate India's governance crisis. Business Week, 4117, 78-79.

Lanis, R., \& Richardson, G. (2015). Is corporate social responsibility performance associated with tax avoidance. Journal of Business Ethics, 127(2), 439-457.

Lee, S., \& Oh, K. K. (2007). Corruption in Asia: Pervasiveness and arbitrariness. Asian Pacific Journal of Management, 24, 97-114.

Li, S., Fetscherin, M., Alon, I., Lattemann, C., \& Yeh, K. (2010). Corporate social responsibility in emerging markets. Management International Review, 50(5), 635-654.

Li, Y., Yao, F. K., \& Ahlstrom, D. (2014). The social dilemma of bribery in emerging economies: A dynamic model of emotion, social value, and institutional uncertainty. Asia Pacific Journal of Management, 32(2), 311-334.

Lin, C. P., Hsiao, L. T., \& Chuang, C. M. (2015). The board of directors and corporate social performance under weak institutions. Asian Business \& Management, 14(2), 117-145.

Luo, Y. (2006). Political behavior, social responsibility, and perceived corruption: A structuration perspective. Journal of International Business Studies, 37(6), 747-766.

Mani, D. (2019). Who controls the Indian economy: The role of families and communities in the Indian economy. Asia Pacific Journal of Management, in press.

March, J.G., \& Olsen, J.P. (1989). Rediscovering institutions: The organizational basis of politics (1st ed.), The Free Press.

Marquis, C., Toffel, M. W., \& Zhou, Y. (2016). Scrutiny, norms, and selective disclosure: A global study of greenwashing. Organization Science, 27(2), 483-504.

McWilliams, A., Siegel, D. S., \& Wright, P. M. (2006). Corporate social responsibility: Strategic implications. Journal of Management Studies, 43(1), 1-18.

Mishra, S., \& Suar, D. (2010). Does corporate social responsibility influence firm performance of Indian companies? Journal of Business Ethics, 95, 571-601.

Mitra, R. (2012). "My Country's future": A culture-centered interrogation of corporate social responsibility in India. Journal of Business Ethics, 106(2), 131-147.

Montiel, I., \& Delgado-Ceballos, J. (2014). Defining and measuring corporate sustainability: Are we there yet. Organization \& Environment, 27(2), 113-139.

Montiel, I., Husted, B. W., \& Christmann, P. (2012). Using private management standard certification to reduce information asymmetries in corrupt environments. Strategic Management Journal, 33, 1103-1113.

Mukundhan, K. V., Sahasranamam, S., \& Cordeiro, J. J. (2019). Corporate investments in tax havens: Evidence from India. Asian Business \& Management, 18(5), 360-388.

Narwal, M., \& Sharma, T. (2008). Perceptions of corporate social responsibility in India: An empirical study. Journal of Knowledge Globalization, 1(1), 61-79.

Orlitzky, M. (2011). Institutional logics in the study of organizations: The social construction of the relationship between corporate social and financial performance. Business Ethics Quarterly, 21(3), 409-444.

Orlitzky, M., Schmidt, F. L., \& Rynes, S. L. (2003). Corporate social and financial performance: A metaanalysis. Organization Studies, 24(3), 403-411.

Perez-Batres, L. A., Doh, J. P., Miller, V. V., \& Pisani, M. J. (2012). Stakeholder pressures as determinants of CSR strategic choice: Why do firms choose symbolic versus substantive self-regulatory codes of conduct? Journal of Business Ethics, 110(2), 157-172.

Pope, S., \& Wæraas, A. (2016). CSR-washing is rare: A conceptual framework, literature review, and critique. Journal of Business Ethics, 137(1), 173-193.

Pureza, A. P., \& Lee, K. (2020). Corporate social responsibility leadership for sustainable development: An institutional logics perspective in Brazil. Corporate Social Responsibility and Environmental Management, 27(3), 1410-1424.

Ralston, D. A., Egri, C. P., Karam, C. M., Naoumova, I., Srinivasan, N., Casado, T., Li, Y., \& Alas, R. (2015). The triple-bottom-line of corporate responsibility: Assessing the attitudes of present and future business professionals across the BRICs. Asia Pacific Journal of Management, 32(1), $145-179$.

Redfern, K., \& Crawford, J. (2010). Regional differences in business ethics in the People's Republic of China: A multi-dimensional approach to the effects of modernisation. Asia Pacific Journal of Management, 27(2), 215-235.

Roodman, D. (2009). How to do xtabond2: An introduction to difference and system GMM in Stata. The Stata Journal, 9(1), 86-136. 
Sagar, P., \& Singla, A. (2004). Trust and corporate social responsibility: Lessons from India. Journal of Communication Management, 8(3), 282-290.

Servaes, H., \& Tamayo, A. (2013). The impact of corporate social responsibility on firm value: The role of customer awareness. Management Science, 59, 1045-1061.

Shiu, Y. M., \& Yang, S. L. (2017). Does engagement in corporate social responsibility provide strategic insurance-like effects? Strategic Management Journal, 38(2), 455-470.

Singh, N., Jain, S., \& Sharma, P. (2014). Determinants of proactive environmental management practices in Indian firms: An empirical study. Journal of Cleaner Production, 66, 469-478.

Singla, C., Veliyath, R., \& George, R. (2014). Family firms and internationalization-governance relationships: Evidence of secondary agency issues. Strategic Management Journal, 35(4), 606-616.

Transparency International (2017). People and corruption: Asia Pacific. Available at: https://www.trans parency.org/whatwedo/publication/people_and_corruption_asia_pacific_global_corruption_barom eter. Last access: 3 August 2020.

Visser, W. (2008). Corporate social responsibility in developing countries. In A. Crane, A. McWilliams, D. Matten, J. Moon, \& D. Siegel (Eds.), The Oxford handbook of corporate social responsibility (pp. 473-479). Oxford University Press.

Wang, Y., \& Berens, G. (2015). The impact of four types of corporate social performance on reputation and financial performance. Journal of Business Ethics, 131(2), 337-359.

Wang, Q., Dou, J., \& Jia, S. (2016). A meta-analytic review of corporate social responsibility and corporate financial performance: The moderating effect of contextual factors. Business \& Society, 55(8), 1083-1121.

Wood, D. J., Mitchell, R. K., Agle, B. R., \& Bryan, L. M. (2018). Stakeholder identification and salience after 20 years: Progress, problems, and prospects. Business \& Society, 1-50.

Woolridge, J. M. (2002). Econometric Analysis of cross section and panel data, 2ed. MIT press.

Wright, M., Filatotchev, I., Hoskisson, R. E., \& Peng, M. W. (2005). Strategy research in emerging economies: Challenging the conventional wisdom. Journal of Management Studies, 42(1), 1-33.

Xiao, C., Wang, Q., van der Vaart, T., \& van Donk, D. P. (2018). When does corporate sustainability performance pay off? The impact of country-level sustainability performance. Ecological Economics, $146,325-333$.

Xu, Y. \& Zeng, G. (2020). Corporate social performance aspiration and its effects. Asia Pacific Journal of Management, in press.

Yang, J., \& Rhee, J. H. (2020). CSR disclosure against boycotts: Evidence from Korea. Asian Business \& Management, 19, 311-343.

Ye, Y., \& Li, K. (2021). Impact of family involvement on internal and external corporate social responsibilities: Evidence from Chinese publicly listed firms. Corporate Social Responsibility and Environmental Management, 28(1), 352-365.

Yu, A., Ding, H. B., \& Chung, H. M. (2015). Corporate social responsibility performance in family and non-family firms: The perspective of socio-emotional wealth. Asian Business \& Management, 14(5), 383-412.

Zhao, M., Tan, J., \& Park, S. H. (2014). From voids to sophistication: Institutional environment and MNC CSR crisis in emerging markets. Journal of Business Ethics, 122(4), 655-674.

Publisher's Note Springer Nature remains neutral with regard to jurisdictional claims in published maps and institutional affiliations. 